\title{
Structural and functional responses of microbial mats to reductions in nutrient and salinity stressors in a Bahamian hypersaline lagoon
}

\author{
James L. Pinckney ${ }^{1, *}$, Richard A. Long ${ }^{1}$, Hans W. Paerl ${ }^{2}$ \\ ${ }^{1}$ Marine Science Program and Department of Biological Sciences, University of South Carolina, Columbia, \\ South Carolina 29208, USA \\ ${ }^{2}$ Institute of Marine Sciences, University of North Carolina at Chapel Hill, 3431 Arendell Street, Morehead City, \\ North Carolina 28557, USA
}

\begin{abstract}
Microbial mats in Bahamian hypersaline lagoons are affected by the combination of salinity fluctuations and external nutrient inputs, both of which are seasonally variable. The purpose of this study was to examine the singular and combined effects of salinity and nutrient (N+P) stress on primary production, extracellular enzyme activity, and the composition of the photoautotroph community in this episodically varying extreme environment. Anoxygenic phototrophic bacteria were able to increase their relative abundance when nutrients were supplied under hypersaline conditions (300 $\left.\mathrm{g} \mathrm{l}^{-1}\right)$. When salinities were lowered $\left(38 \mathrm{~g} \mathrm{l}^{-1}\right)$ and nutrients added, extracellular enzyme activity (aminopeptidase, $\alpha$-glucosidase, and $\beta$-glucosidase), rates of oxygenic photosynthesis, and phototroph biomass increased in the oxic surface layers of the mat. Once salinity stress had been lowered, oxygenic photosynthesis allowed the proliferation of Cyanobacteria, heterotrophic activity, and a corresponding reduction in the abundance of anoxygenic phototrophic bacteria. On reduction of nutrient stress, mat phototrophs responded by increasing biomass (using either anoxygenic or oxygenic photosynthesis, or both). In this hypersaline system, seasonal as well as short-term (days) variations in environmental conditions may promote structural changes in the mat community which alter the rates of major processes such as oxygenic photosynthesis and heterotrophy, and illustrate the cyclic behavior of microbial dormancy and proliferation in this extreme environment. Cycles in nutrient input and salinity are primary forcing factors for the maintenance of a dynamic and diverse (both structurally and functionally) benthic microbial community in a small hypersaline lagoon, Salt Pond, on San Salvador Island, Bahamas.
\end{abstract}

KEY WORDS: Cyanobacteria $\cdot$ Photopigments $\cdot$ HPLC $\cdot$ Enzymes $\cdot$ Productivity Resale or republication not permitted without written consent of the publisher

\section{INTRODUCTION}

Hypersaline systems, such as lagoons, evaporative lakes, and salterns are commonly inhabited by benthic microbial mats composed of phototrophic Cyanobacteria, diatoms, and diverse chemoheterotrophic and chemoautotrophic bacteria (Cohen \& Rosenberg 1989, Stal 1995, Oren 2000, Abed et al. 2008, Green et al. 2008). Calm, protected conditions and clear, shallow waters provide ideal environments for the prolific growth of structurally and functionally well-developed microbial mats (Black 1933, Neumann et al. 1970,
Pinckney et al. 1995). These systems are frequently nitrogen depleted, and primary productivity relies on inputs of nitrogen through the activity of nitrogen-fixing diazotrophs (Cyanobacteria and diverse members of Alpha-, Beta-, and Gammaproteobacteria) as well as allochthonous sources in rainfall and runoff (Stal 1995, Camacho \& de Wit 2003, Omoregie et al. 2004, Yannarell et al. 2006).

In Salt Pond, a small hypersaline lagoon on San Salvador Island, Bahamas, the microbial mats, which are dominated by Cyanobacteria, are well-developed in terms of abundance, biomass, and primary production 
(Paerl et al. 1993, Pinckney et al. 1995, Yannarell et al. 2006, Yannarell \& Paerl 2007). Maximum rates of production and nitrogen fixation occur in a $<10 \mathrm{~mm}$ thick surface layer during the daytime and nighttime, respectively (Paerl et al. 1996). Purple anoxygenic photosynthetic bacteria (Chromatium sp.) and chemolithotrophic bacteria (Beggiatoa sp.) migrate from deeper layers to the surface during periods of anoxia in the sediments (Paerl et al. 2003). In the dry months, evaporation leads to hypersaline conditions in which Cyanobacteria are the primary nitrogen-fixers. During wet periods, a more diverse community of bacterial diazotrophs develops within the mat (Yannarell et al. 2006). On annual time scales, the primary environmental control on microbial activity in this lagoon appears to be salinity, which may range from as low as 60 to $90 \mathrm{~g} \mathrm{l}^{-1}$ in the wet season (September-January) to a maximum of $340 \mathrm{~g} \mathrm{l}^{-1}$ at the end of the dry season in July and August (see Fig. 1) (Yannarell et al. 2006). Lower salinity generally promotes higher metabolic activity, and experimental reduction in salinity results in elevated rates of primary production and nitrogen fixation in less than $2 \mathrm{~d}$ (Paerl et al. 2003).

The relatively small size (5.0 ha) and shallow waters $(<1 \mathrm{~m})$ of Salt Pond allow rapid, major changes in salinity. Freshwater inputs from runoff and direct deposition during rainfall events affect submerged mats as well as those subaerially exposed in the littoral zone. Salinity can range from freshwater (rainfall on salt-encrusted subaerial mats) to reductions of pondwater salinity by as much as $60 \%$ following major rains (Yannarell et al. 2007). Furthermore, rain may import allochthonous nutrients and organic matter that stimulate microbial activity (Yannarell et al. 2007). The focus of our research was to quantify the effects of these rapid salinity alterations on microbial mat structure and function using a series of manipulative bioassays.

Previous studies have demonstrated that microbial mats in Salt Pond are affected by the combination of salinity fluctuations and external inputs of the growthlimiting nutrients nitrogen $(\mathrm{N})$ and phosphorus $(\mathrm{P})$, both of which are variable over time (Pinckney et al. 1995, Pinckney \& Paerl 1997, Paerl et al. 2000, 2003, Yannarell \& Paerl 2007, Paerl \& Yanarell 2010). However, the primary focus of previous studies was the determination of functional responses of the community (e.g. primary productivity, nitrogen fixation) rather than detailed examinations of structural changes of the phototrophic community in response to nutrient/salinity manipulations. Microbial responses to rapid and simultaneous changes in both of these factors offer insight into the processes that define the structural and functional characteristics of this diverse and tightlycoupled community. The purpose of the present study was to examine the individual and synergistic effects of salinity and nutrients $(\mathrm{N}+\mathrm{P})$ on both the structural (photoautotroph relative abundances) and functional (primary production, enzyme activity) responses of the microbial mat community in Salt Pond to assess the potential impacts of rapid changes in nutrient and salinity conditions similar to those encountered during episodic rainfall events.

\section{MATERIALS AND METHODS}

The island of San Salvador, Bahamas $\left(24^{\circ} 05^{\prime} \mathrm{N}\right.$, $\left.74^{\circ} 30^{\prime} \mathrm{W}\right)$, has a subtropical, semiarid climate, with a mean annual rainfall of $101 \mathrm{~cm}$. In a typical year, just under half of the rainfall occurs during tropical storms in the wet season from mid-September through late November (Shaklee 1996, Paerl et al. 2003). Salt Pond $\left(24^{\circ} 01^{\prime} \mathrm{N}, 74^{\circ} 27^{\prime} \mathrm{W}\right)$ is a shallow (<1.0 m) hypersaline lagoon (5.0 ha) located on the central eastern side of San Salvador. The water volume of Salt Pond varies with the wet and dry seasons, and salinity ranges from 67 to $340 \mathrm{~g} \mathrm{l}^{-1}$ (median $=168 \mathrm{~g} \mathrm{l}^{-1}$ ) (Fig. 1). Carbonate sands, including portions of the arid littoral zone, are covered by microbial mats consisting of benthic diatoms and non-heterocystous Cyanobacteria of the orders Oscillatoriales, Chroococcales, and Pleurocapsales (Pinckney \& Paerl 1997, Paerl et al. 2003, Yannarell et al. 2006). Deep cores reveal alternating periods of prolific mat growth, sedimentation events, and a layer of gypsum $\left(\mathrm{CaSO}_{4} \cdot 2 \mathrm{H}_{2} \mathrm{O}\right)$ at ca. $1 \mathrm{~m}$ in the sediment. The $\mathrm{pH}$ of the hypersaline water in Salt Pond is a constant 7.95 to 8.00. Six-year (2000-2006) median values for nutrients $\left(\mathrm{NO}_{2}{ }^{-}+\mathrm{NO}_{3}{ }^{-}\right.$, $\left.\mathrm{NH}_{4}{ }^{+}, \mathrm{PO}_{4}{ }^{3-}, \mathrm{Si}\right)$ in the waters of the lagoon were 0.8 , $14.5,0.3$, and $33 \mu \mathrm{mol} \mathrm{l}^{-1}$, respectively, and mean N:P and N:Si molar ratios were 71 and 0.9 , respectively (Paerl et al. unpubl.).

On 26 June 2004, cores of subaerially-exposed microbial mat $(4.0 \times 4.0 \times 1.0 \mathrm{~cm})$ were collected from moist sediments in the littoral zone midway between the waterline and shoreline during a period of extreme hypersalinity (300 to $330 \mathrm{~g} \mathrm{l}^{-1}$ ) and temperature $\left(>40^{\circ} \mathrm{C}\right)$ in Salt Pond (Fig. 1). Six cores of mat material were randomly placed upright in 12-well polystyrene tissue culture plates (Falcon). Experimental manipulations consisted of 12 replicate mat core incubations in Salt Pond water $\left(300 \pm 10 \mathrm{~g} \mathrm{l}^{-1}\right.$, mean \pm $\mathrm{SD})$, seawater $\left(38 \pm 5 \mathrm{~g} \mathrm{l}^{-1}\right)$, and freshwater $(2.0 \pm 2 \mathrm{~g}$ $\left.\mathrm{l}^{-1}\right)$. Nitrate and phosphate $\left(500 \mu \mathrm{mol} \mathrm{l^{-1 }} \mathrm{NO}_{3}^{-}\right.$as $\mathrm{KNO}_{3}$ and $500 \mathrm{mmol} \mathrm{l}^{-1} \mathrm{PO}_{4}{ }^{3-}$ as $\mathrm{KH}_{2} \mathrm{PO}_{4}$, final concentrations) were added to one-half of the samples (Table 1). Culture plates were submerged to a water depth of $10 \mathrm{~cm}$ in plastic containers $(50 \times 50 \times 25 \mathrm{~cm})$ filled with the incubation water for the different salinity and nutrient treatments. This design resulted in 


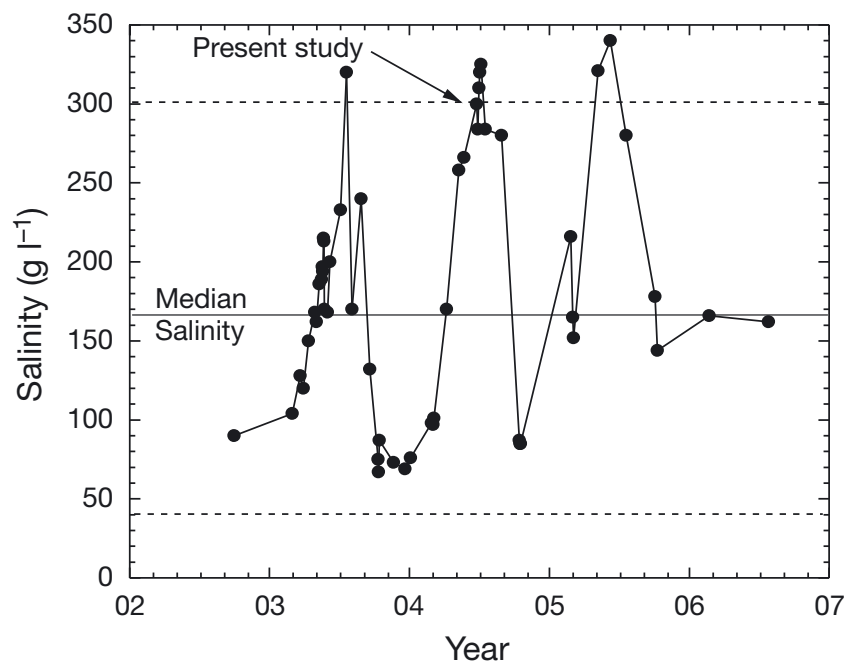

Fig. 1. Salinity $\left(\mathrm{g} \mathrm{l}^{-1}\right)$ in Salt Pond, San Salvador Island, Bahamas, from 2002 to 2006 . Salinity at the time of the bioassays is indicated by an arrow, and the horizontal dashed lines show the salinities for the bioassays. Solid horizontal line indicates the median salinity over the time period

12 replicates (in 2 culture plates) for each of 6 treatment levels in a fully-crossed statistical design. Incubation containers were placed outside under ambient irradiance in small tanks continually flushed with flowing seawater $\left(0.05 \mathrm{l} \mathrm{s}^{-1}\right)$ for temperature control (30 to $36^{\circ} \mathrm{C}$ ). Salinity was checked daily using a refractometer $( \pm 0.2 \%)$ and adjusted (by adding freshwater) to maintain the desired concentrations. After $10 \mathrm{~d}$, the incubations were terminated and assayed for primary productivity, photopigment abundance, and enzyme activity. This manipulative experiment was designed to simulate salinity and nutrient exposures under ambient conditions as well as following a rain event (Table 1). Thus mats were not pre-acclimated to nutrients or salinities prior to the manipulations because the overall goal was to determine the short-

Table 1. Bioassay design summary and corresponding abbreviations used in the text. There were 12 replicates for each treatment for a total of 72 individual core samples (each $4.0 \mathrm{~cm}^{2}$ ) used in the experiment

\begin{tabular}{|c|c|c|c|}
\hline Designation & Description & $\begin{array}{l}\text { Salinity } \\
\left(\mathrm{g} \mathrm{l}^{-1}\right)\end{array}$ & $\begin{array}{l}\text { Addition } \\
\left(\mu \mathrm{mol} \mathrm{l}^{-1}\right)\end{array}$ \\
\hline FW Ctrl & Freshwater, control & 2 & Ambient nutrients \\
\hline FW N+P & $\begin{array}{l}\text { Freshwater, } \\
\text { nutrient addition }\end{array}$ & 2 & $500 \mathrm{NO}_{3}{ }^{-}+500 \mathrm{PO}_{4}{ }^{3-}$ \\
\hline SW Ctrl & Seawater, control & 38 & Ambient nutrients \\
\hline $\mathrm{SW} N+\mathrm{P}$ & $\begin{array}{l}\text { Seawater, } \\
\text { nutrient addition }\end{array}$ & 38 & $500 \mathrm{NO}_{3}{ }^{-}+500 \mathrm{PO}_{4}{ }^{3-}$ \\
\hline SP Ctrl & Salt Pond water, control & 300 & Ambient nutrients \\
\hline $\mathrm{SP} N+\mathrm{P}$ & $\begin{array}{l}\text { Salt Pond water, } \\
\text { nutrient addition }\end{array}$ & 300 & $500 \mathrm{NO}_{3}{ }^{-}+500 \mathrm{PO}_{4}{ }^{3-}$ \\
\hline
\end{tabular}

term $(10 \mathrm{~d})$ mat responses to the extreme ranges of salinity and nutrients likely experienced in Salt Pond. Episodic rain events are common and reflected by rapid changes in pondwater salinities (Fig. 1).

Gross primary production was measured with oxygen microelectrodes (Unisense; $20 \mu \mathrm{m}$ tip diameter) using the light/dark shift method (Revsbech \& Jørgensen 1986). Productivity measurements consisted of illuminating the sample with a fiber-optic light (ca. $1500 \mu \mathrm{mol}$ photons $\mathrm{m}^{-2} \mathrm{~s}^{-1}$ ) and measuring the initial slope of oxygen decrease at $100 \mu \mathrm{m}$ depth intervals within 1 to $2 \mathrm{~s}$ after darkening the sediment surface (Revsbech \& Jørgensen 1986, Pinckney \& Zingmark 1993). All measurements were undertaken after oxygen concentrations had achieved a steady state as determined by microelectrode profiles in the sample. Contact between the tip of the microelectrode and the mat surface was observed with a small magnifying lens $(25 \times)$. Productivity was measured at successive intervals of $100 \mu \mathrm{m}$ until there was no detectable response within $5 \mathrm{~s}$ of the light/dark shift. Data were acquired and processed using Sloper software (Unisense). The measured rate at each depth interval was then integrated over all depth intervals to give a depth-integrated areal estimate of gross primary production (GPP). Three vertical profiles of production were obtained at random locations within each sample. Depth-integrated GPP for all 3 profiles was averaged to provide an estimate of total community production for each sample. GPP was determined for 6 of the 12 samples in each of the 6 treatments (108 production profiles, 36 GPP estimates, 6 treatments, 6 replicates). Productivity measurements were obtained under subaerial (i.e. not submerged) exposure conditions to minimize the potential effects of salinity-related oxygen diffusion constraints (Sherwood et al. 1991, Garcia-Pichel et al. 1999) and therefore represent maximum potential rates of GPP for comparisons among the different treatments.

Subsamples $(1.0 \times 1.0 \times 0.3 \mathrm{~cm})$ from each of the productivity samples were collected for photopigment analysis, stored in $2 \mathrm{ml}$ microfuge tubes, and immediately frozen. High-performance liquid chromatography (HPLC) was used to determine chemosystematic photosynthetic pigments for mat photoautotrophs. Mat samples were lyophilized for $24 \mathrm{~h}$ at $-50^{\circ} \mathrm{C}$, placed in $90 \%$ acetone $(1.00 \mathrm{ml})$, sonicated, and extracted at $-20^{\circ} \mathrm{C}$ for 18 to 20 h. Filtered extracts $(200 \mu \mathrm{l})$ were injected into a Shimadzu HPLC apparatus equipped with a monomeric (Rainin Microsorb-MV, $0.46 \times 10 \mathrm{~cm}$, 
$3 \mu \mathrm{m}$ ) and a polymeric (Vydac 201TP54, $0.46 \times 25 \mathrm{~cm}$, $5 \mu \mathrm{m})$ reverse-phase $\mathrm{C} 18$ column in series. A nonlinear binary gradient consisting of the solvents $80 \%$ methanol:20\% $0.50 \mathrm{M}$ ammonium acetate and $80 \%$ methanol:20\% acetone was used for pigment separations (Pinckney et al. 1996). Absorption spectra and chromatograms $(440 \pm 4 \mathrm{~nm})$ were acquired using a Shimadzu SPD-M10av photodiode array detector. Pigment peaks were identified by comparison of retention times and absorption spectra with pure standards (DHI). The synthetic carotenoid $\beta$-apo-8'-carotenal (Sigma) was used as an internal standard.

Ectoenzymatic activity of the microbial community was assayed as an indicator of the response of the heterotrophic community to the experimental manipulations. 4-methylumbelliferone-conjugated substrate analogs (MUF) were used to measure enzyme activity associated with the breakdown of carbohydrates (i.e. $\beta$-glucosidase and galactosidase), and mono-phosphoesters (i.e. alkaline phosphatase; Sigma) (Hoppe 1983). An aminomethyl-coumarin-conjugated substrate ana$\log (\mathrm{AMC})$ was used to measure leucine-aminopeptidase activity (Sigma). Due to limited quantities of mat material, assays were conducted in duplicate for each of the incubation treatments at the termination of the experiment, with a single heat-killed control. Three sub-cores were taken from each core and divided into quarters, and the upper $3 \mathrm{~mm}$ of mat material was transferred to a test tube. Water $(3 \mathrm{ml})$ from respective salinity treatments was added to the sample with 100 $\mu \mathrm{M}$ of MUF/AMC-substrate. Samples were incubated at in situ temperatures for $10 \mathrm{~min}$. Prior to measuring the fluorescence signal (excitation $365 \mathrm{~nm}$, emission $460 \mathrm{~nm}$ ) the sample was briefly vortexed to mix the liquid without disrupting the structure of the core. Then, a $1.5 \mathrm{ml}$ sub-aliquot was taken, measured and returned to the test-tube. Samples were incubated for an additional 10 min and a second measurement was taken. A subset of the cores was dried and weighed. The fluorescence signal was calibrated using either MUF or AMC standards prepared using water from the respective salinity/nutrient treatments and normalized to time and sample dry weight.

\section{RESULTS}

\section{Primary productivity}

Gross primary production (GPP) measured after $10 \mathrm{~d}$ incubation ranged from 0 to $2.39 \pm 0.44 \mu \mathrm{mol} \mathrm{O} \mathrm{Cm}^{-2}$ $\mathrm{h}^{-1}$ (mean $\pm \mathrm{SD}$ ) (Fig. 2). A single-factor ANOVA indicated a significant treatment effect $\left(F_{5,30}=62.63, \mathrm{p}<\right.$ 0.001) and a Dunnett's T3 post hoc comparison of means indicated 3 homogeneous groups $(p \leq 0.05)$. The

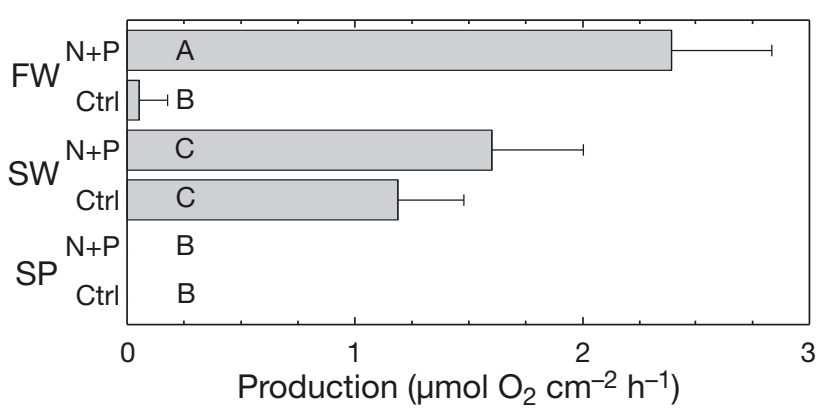

Fig. 2. Gross primary production for the 6 experimental treatments (see Table 1). Bars represent mean + SD for 6 replicates. Letters A, B, and C indicate the results of a posteriori multiple comparisons of means. Bars which share the same letters were not significantly different $(p>0.05)$. No oxygenic photosynthesis was detected in the initial (time 0) or the SP samples

FW N+P (freshwater, nutrient addition) treatment had the highest GPP, followed by SW Ctrl (seawater, control) and SW N+P (seawater, nutrient addition). GPP in all other treatments was undetectable. Vertical profiles of steady-state dissolved $\mathrm{O}_{2}$ concentrations in the mats were consistent with the productivity results (Fig. 3). The upper $15 \mathrm{~mm}$ of mats exposed to the SW Ctrl, SW $\mathrm{N}+\mathrm{P}$, and $\mathrm{FW} \mathrm{N}+\mathrm{P}$ treatments showed supersaturated concentrations of $\mathrm{O}_{2}$ while the other 3 treatments were essentially hypoxic/anoxic.

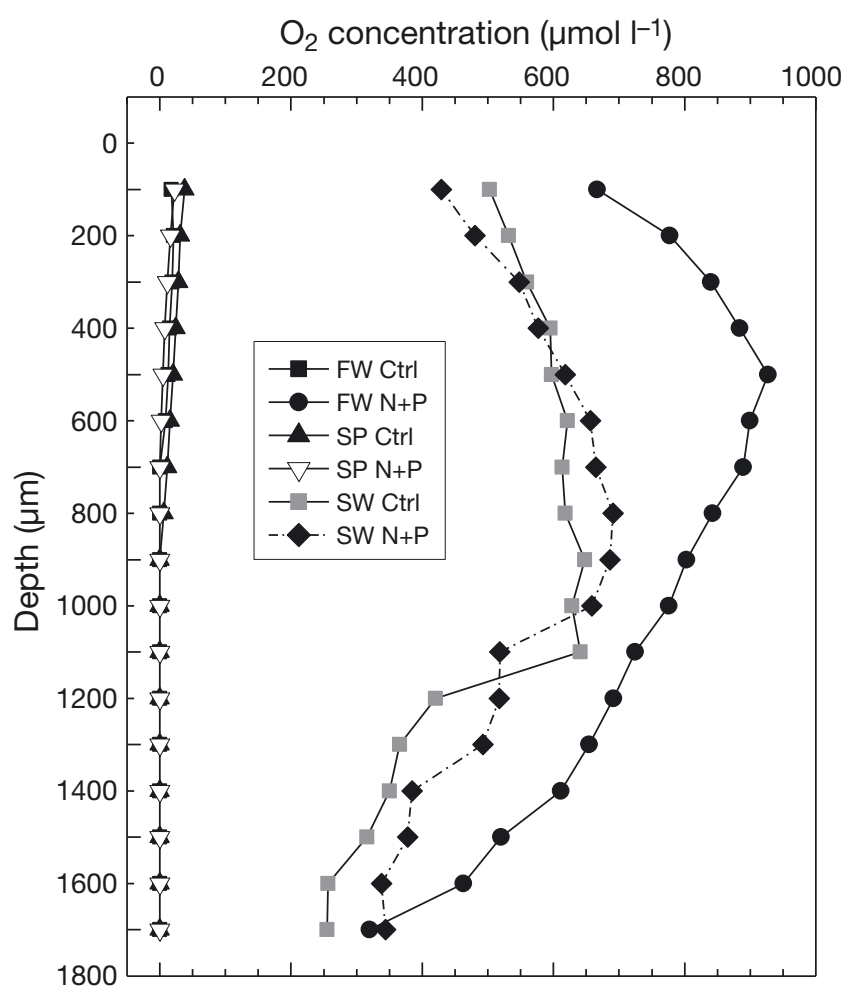

Fig. 3. Representative profiles of the vertical distribution of steady-state dissolved oxygen concentrations for each of the experimental treatments (see Table 1) 


\section{Ectoenzyme activity}

Enzyme activity measurements on duplicate samples for $\alpha$-glucosidase activity ranged from 2.93 to $8.31 \mathrm{nmol} \mathrm{g}^{-1} \mathrm{~h}^{-1}$ and was highest in the SW N+P treatment (Fig. 4). The activity of $\beta$-glucosidase had a range of 2.43 to $12.62 \mathrm{nmol} \mathrm{g}^{-1} \mathrm{~h}^{-1}$ with higher rates in the SW (seawater) incubations. Similarly, aminopeptidase activity was highest in the SW treatments and ranged from 2.06 to $129.2 \mathrm{nmol} \mathrm{g}^{-1} \mathrm{~h}^{-1}$. Alkaline phosphatase activity was highly variable $\left(6.81\right.$ to $\left.>500 \mathrm{nmol} \mathrm{g}^{-1} \mathrm{~h}^{-1}\right)$, with the highest rates in the SP (Salt Pond) treatments, followed by the SW control, SW N+P, and FW (freshwater) treatments. With the exception of alkaline phosphatase, enzyme activities were generally higher in the treatments that exhibited oxygen supersaturation in the upper mat layers. The highest alkaline phosphatase activity occurred in the anoxic samples.

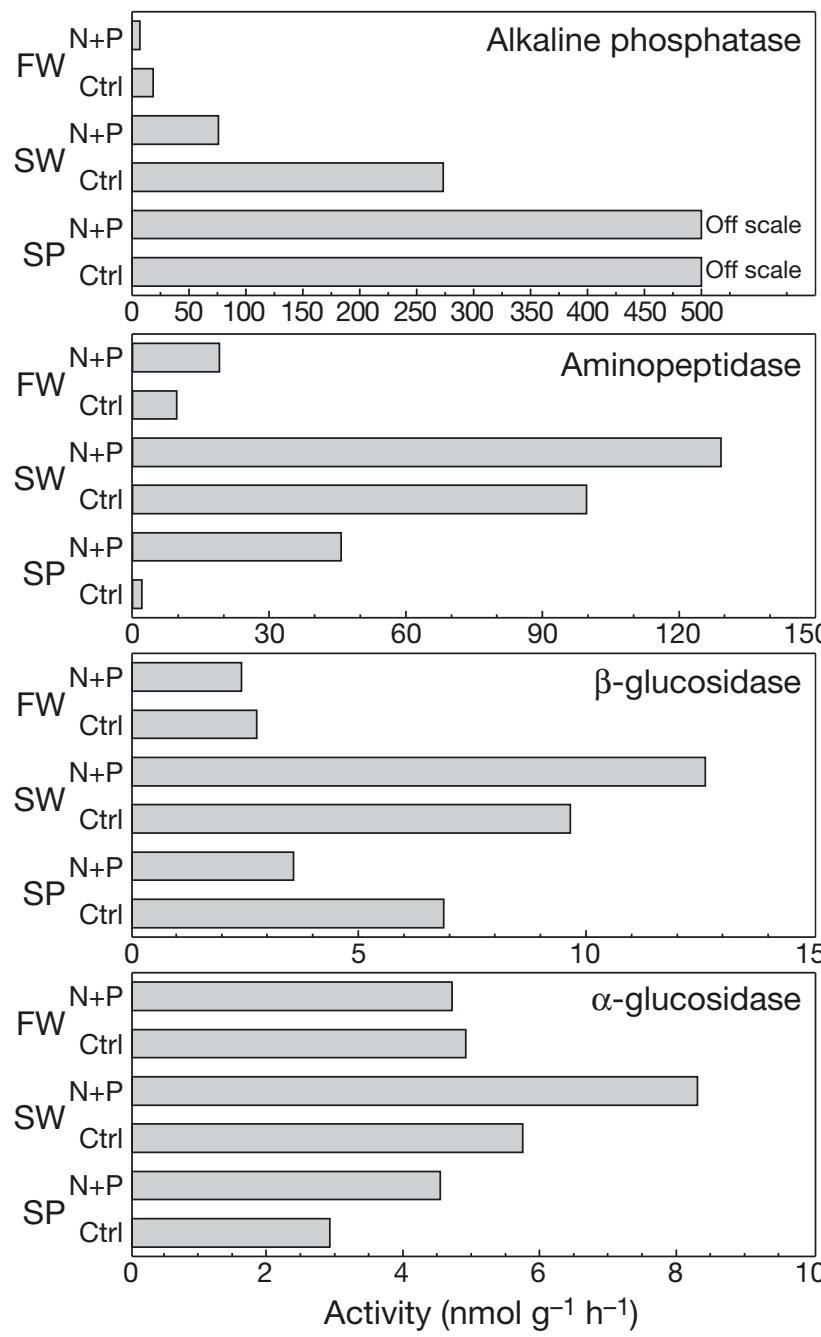

Fig. 4. Ectoenzyme activities for each of the experimental treatments. Bars represent the average of duplicate measurements (see Table 1)

\section{Photopigment abundances}

The most commonly detected photopigments were chlorophyll a (chl a), bacteriochlorophyll a (bchl a), echinenone myxoxanthophyll, zeaxanthin, $\alpha$-carotene, $\beta$-carotene and the photoprotective pigment scytonemin. The photopigment composition indicated that the phototroph community was composed almost exclusively of Cyanobacteria and anoxygenic phototrophic bacteria (Fig. 5). For the bioassays, photopigment abundances were analyzed using a single-factor multivariate analysis of variance (MANOVA) with treatment as the factor (6 levels) and pigment abundances as the variates (10 pigments). The MANOVA indicated a significant treatment effect (Pillai's Trace, $F_{50,110}=$ 5.63, $\mathrm{p}<0.001)$. The univariate ANOVAs showed sig-

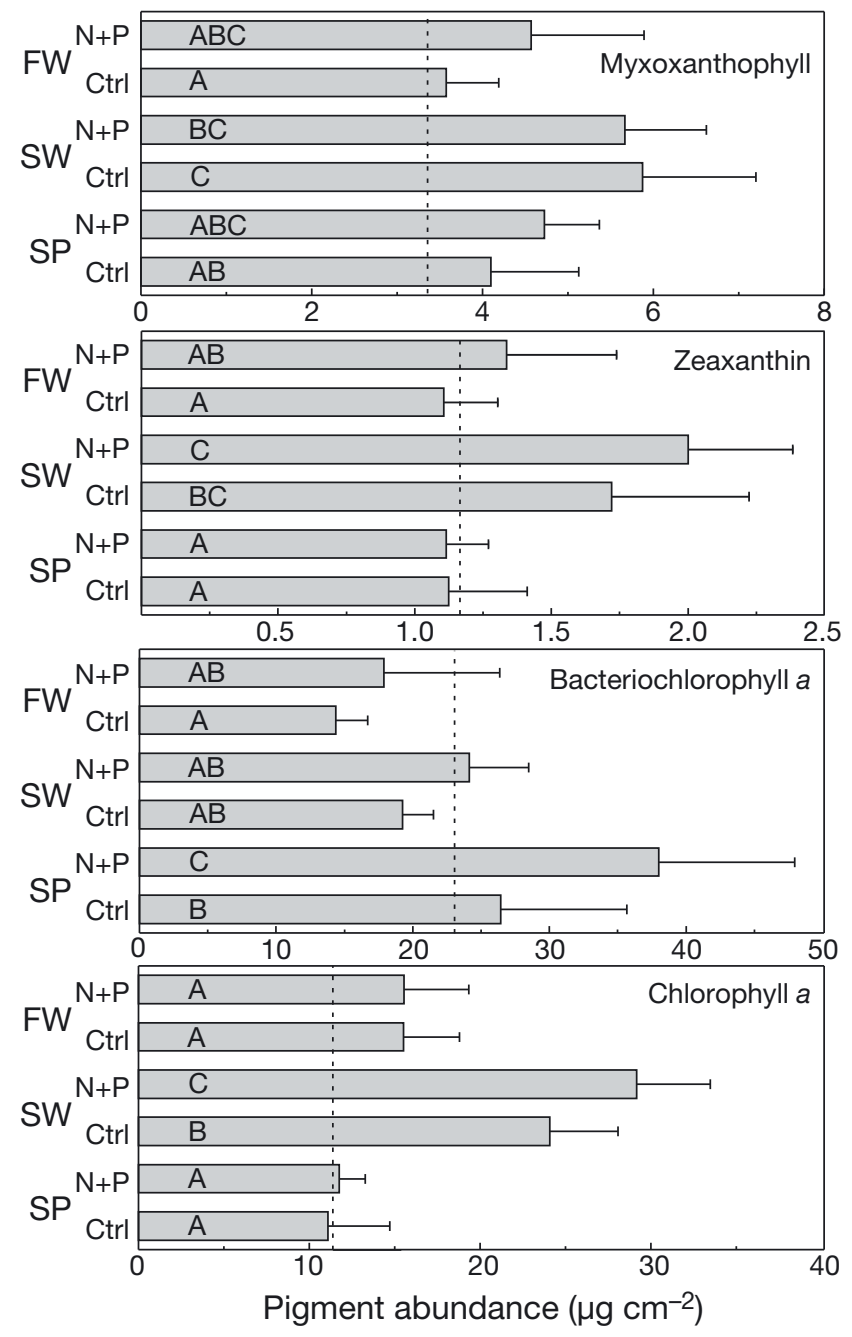

Fig. 5. Photopigment abundances for each of the experimental treatments (see Table 1). Bars represent mean + SD for 6 replicates. Letters A, B, and C indicate the results of a posteriori multiple comparisons of means. Bars which share the same letters were not significantly different $(p>0.05)$. Vertical dashed lines indicate initial pigment concentrations (time 0) 
nificant treatment effects for all pigments $(p \leq 0.05$, power $\geq 0.71)$ except echinenone $(p=0.945$, power $=$ 0.096). Mean abundances for each treatment level were compared using the Bonferroni multiple comparisons test ( $\mathrm{p} \leq 0.05$ ) (Fig. 5). For chl $a$, abundances were higher in the SW treatment. The indicator pigment for anoxygenic phototrophic bacteria, bchl $a$, was highest in the SP water and lowest in the FW treatment. The cyanobacterial pigments zeaxanthin and myxoxanthophyll were highest in the SW incubations. The only significant nutrient addition effects were for chl a in SW and bchl $a$ in SP.

Discriminant analysis was performed following the MANOVA to build a predictive model of group membership based on the observed photopigment abundances for each treatment level in the bioassay (Fig. 6). The first 2 discriminant functions explained 74.7 and $11.2 \%$ of the variance, respectively (cumulative total $=$ $85.9 \%$ ) (Wilks' $\lambda=0.002, \mathrm{p}<0.001$ ). Using these functions, $93.9 \%$ of the samples were correctly classified according to the incubation treatment level. The group centroids, derived from the canonical discriminant functions, suggest that the photopigment composition of mats incubated at lowered salinities differed from those in SP water. Furthermore, photopigment abundances in the $\mathrm{N}+\mathrm{P}$ additions differed from those in the corresponding control (Ctrl) treatments. The notable exception is an absence of a nutrient addition effect for the SP incubated samples. The differences between most of the treatments were best explained by the first discriminant function, while the second function explained the difference between the $\mathrm{N}+\mathrm{P}$ and $\mathrm{Ctrl}$ treatments for the FW incubated mats. The primary difference between the 2 functions was related to a change in sign (i.e. +/-) for the coefficients for myxo-

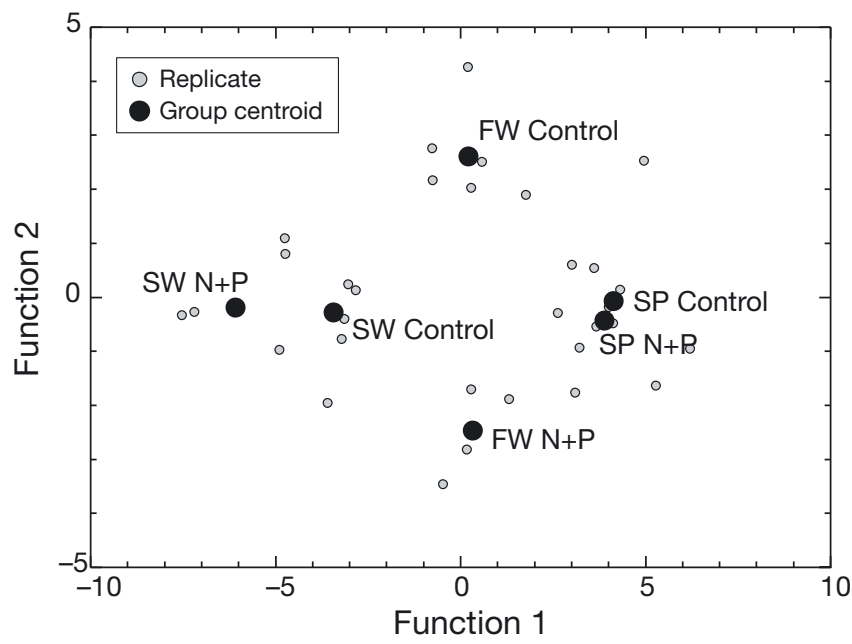

Fig. 6. Canonical discriminant function plot for pigment data classified by experimental treatment (see Table 1). Centroids are labeled with respective treatment levels, and functions for individual data points are indicated by the small circles xanthophyll and chl $a$, suggesting that mat phototroph community differences were primarily attributable to changes in cyanobacterial biomass.

\section{Summary of mat responses}

The microbial mat enzyme activity, productivity, and photopigment responses to the $\mathrm{N}+\mathrm{P}$ additions in the bioassays relative to their respective controls (i.e. no nutrients added) were summarized for each of the salinity treatments (Table 2). The highest increase in chl a occurred in the SW incubation followed by the SP and FW treatments. Bchl a increased in all treatments, with the largest increase in the SP water. $\beta$-carotene increased in the SP and SW treatments and declined in FW. For echinenone, abundances declined in all treatments while myxoxanthophyll declined in the SW treatment and scytonemin was detected in the SP water only. Zeaxanthin increased in SW and FW but remained relatively constant in the SP water. GPP was not detectable in the SP treatment, showed a $35 \%$ increase in SW, and was highest (4500\%) in the FW incubation. For enzymes, $\alpha$-glucosidase activity increased in SW and FW while $\beta$-glucosidase activity decreased in SP and FW. Alkaline phosphatase activity was highest (>500 nmol g ${ }^{-1} \mathrm{~h}^{-1}$ ) in FW but lower relative to controls in SP and SW. Aminopeptidase activity was highest in FW and an order of magnitude lower in SP and SW.

Table 2. Summary of microbial mat responses to nutrient $(\mathrm{N}+\mathrm{P})$ additions. Values are percent higher or lower than respective measurements for controls incubated at the 3 salinity levels (Salt Pond $=300 \mathrm{~g} \mathrm{l}^{-1}$, seawater $=40 \mathrm{~g} \mathrm{l}^{-1}$, freshwater $=$ $2 \mathrm{~g} \mathrm{l}^{-1}$ ). These results highlight the response to nutrient additions within each of the 3 salinity levels

\begin{tabular}{|c|c|c|c|}
\hline & Salt Pond & Seawater & Freshwater \\
\hline Chlorophyll a & 5.9 & 21.1 & 0.2 \\
\hline Bacteriochlorophyll a & 43.8 & 25.4 & 24.5 \\
\hline$\beta$-carotene & 4.0 & 15.6 & 36.4 \\
\hline Echinenone & -20.1 & -20.2 & -5.8 \\
\hline Myxoxanthophyll & 15.2 & -3.5 & 27.8 \\
\hline Scytonemin & 21.5 & $\mathrm{a}$ & $\mathrm{b}$ \\
\hline Zeaxanthin & -0.7 & 16.3 & 20.8 \\
\hline $\begin{array}{l}\text { Gross primary } \\
\text { production }\end{array}$ & 0.0 & 34.8 & 4498 \\
\hline$\alpha$-glucosidase & 55.2 & 44.5 & -4.0 \\
\hline$\beta$-glucosidase & -47.9 & 30.8 & -12.0 \\
\hline ßminopeptidase & 2124 & 29.6 & 96.6 \\
\hline Alkaline phosphatase & c & -72.2 & -63.1 \\
\hline \multicolumn{4}{|c|}{$\begin{array}{l}\text { a Scytonemin was not detected in the } \mathrm{N}+\mathrm{P} \text { treatments } \\
\text { beytonemin was not detected in either control or } \mathrm{N}+\mathrm{P} \\
\text { treatments } \\
{ }^{\mathrm{c}} \text { Activity was off-scale and }>500 \mathrm{nmol} \mathrm{g}^{-1} \mathrm{~h}^{-1}\end{array}$} \\
\hline
\end{tabular}




\section{DISCUSSION}

Seasonal rainfall and evaporation at Salt Pond result in an annual salinity range of 60 to $350 \mathrm{~g} \mathrm{l}^{-1}$. Hypersalinity, coupled with a high exposure to ultraviolet light and summer water temperatures exceeding $40^{\circ} \mathrm{C}$, create extreme environmental conditions within the lagoon. The historical N:P ratios (0 to 1600) suggest a strongly P-limited system, and nutrient concentrations are highly variable over the range of salinities within the pond. However, nutrient concentrations are generally highest when salinities are $>100 \mathrm{~g} \mathrm{l}^{-1}$ (Paerl et al. unpubl.). At salinities $<100 \mathrm{~g} \mathrm{l}^{-1}$, nutrient concentrations are much lower, possibly a result of more rapid utilization and most likely reflects higher activity and growth rates (Abed et al. 2007, Oren 2009). Wieland \& Kühl (2006) reported that a salinity of $100 \mathrm{~g} \mathrm{l}^{-1}$ seems to be a transition point for microbial mats at which a further increase results in higher respiration and lower rates of oxygenic photosynthesis. In Salt Pond, rates of nitrogenase activity and $\mathrm{CO}_{2}$ fixation decrease with increasing salinity (Pinckney et al. 1995, Pinckney \& Paerl 1997, Paerl et al. 2003). The observed relationship between salinity and nutrient concentrations in Salt Pond may reflect physiological changes in mat activity.

In the present study, manipulative bioassays were used to quantify the structural and functional responses of the microbial mat community to shortterm changes in salinity and nutrient concentrations reflecting the extreme range experienced in Salt Pond over an annual cycle. The manipulations simulated exposure of mats in the littoral zone to rainfall (freshwater) and responses were measured after allowing sufficient time $(10 \mathrm{~d})$ for acclimation to the altered salinity and nutrient conditions. Previous studies have shown measurable changes within 2 d (Pinckney \& Paerl 1997, Paerl \& Yanarell 2010). The nutrient additions for the bioassays were ca. 5 to $10 \times$ higher than previously measured levels in the lagoon. These high concentrations were used to minimize the possibility of nutrient limitation during the bioassay. Samples incubated in hypersaline SP water did not exhibit any detectable oxygenic photosynthesis and vertical profiles showed anoxic conditions in surface layers. Alkaline phosphatase activity exceeded $500 \mathrm{nmol} \mathrm{g}^{-1} \mathrm{~h}^{-1}$ in both the control and N+P amended samples and suggests severe P-limitation under hypersalinity and anoxia. However, the addition of nutrients resulted in an increase in the abundance of the photopigments of purple anoxygenic phototrophic bacteria and illustrates the ability of these microbes to grow under anoxic, hypersaline conditions when nutrient levels are elevated. Paerl \& Yanarell (2010) have suggested that the high microbial diversity provides a rapid response to environmental variability because specific members of the community can assume key production and nutrient cycling functions depending on their salinity optima.

An increase in pigment abundance may reflect an increase in the abundance of respective phototroph groups and/or photoacclimation responses of cells. Because irradiance levels were similar for all treatments, photopigment changes due to light acclimation were unlikely. Furthermore, all experimental treatments were compared to appropriate controls for statistical tests.

The incubations at seawater salinity (38 $\mathrm{g}^{-1}$ ) showed high rates of photosynthesis relative to the controls, and increases in the abundances of chl $a$ and the cyanobacterial pigment zeaxanthin. This response indicates an increase in oxygenic photosynthesis and growth by Cyanobacteria when salinity stress is reduced. The elevated activities of the extracellular enzymes aminopeptidase, $\alpha$-glucosidase, and $\beta$-glucosidase suggest a similar heterotrophic response to lower salinity and oxygenation of the surface layers of the mat. Previous studies in Salt Pond have demonstrated the rapid uptake of dissolved organic carbon and organic nitrogen compounds by mat microbes following reductions in salinity (Paerl \& Yanarell 2010). The addition of inorganic nutrients ( $\mathrm{N}$ and $\mathrm{P}$ ) at the lowered salinity resulted in higher glucosidase activities and higher chl a abundances but lower alkaline phosphatase activities relative to the corresponding control treatment. This response indicates that once salinity stress is reduced, nutrient concentrations become an important determinant of mat activity. The lowered alkaline phosphatase activity in the nutrient treatment provides some evidence that $\mathrm{P}$ may be the primary limiting nutrient under these conditions. Although the cyanobacterial pigment zeaxanthin did not exhibit a significant increase in abundance in the nutrient treatment, the general trend mirrored the increase in chl a and suggests cyanobacterial growth. The reduction in salinity from 300 to $38 \mathrm{~g} \mathrm{l}^{-1}$ stimulated mat oxygenic photosynthesis for both the $\mathrm{N}+\mathrm{P}$ and Ctrl treatments. The enhanced rates of GPP without a large increase in cyanobacterial biomass provides indirect evidence that Cyanobacteria can quickly switch from anoxygenic to oxygenic photosynthesis depending on the ambient environmental conditions (Jørgensen et al. 1986, de Wit et al. 1988, Pringault \& Garcia-Pichel 2000).

At a salinity of $2 \mathrm{~g} \mathrm{l}^{-1}$, there was a reduction in the abundance of bchl a along with a low alkaline phosphatase activity, and only the $\mathrm{N}+\mathrm{P}$ treatment showed a significant increase in GPP $(p<0.05)$. The observed vertical distribution of dissolved oxygen is consistent with the productivity measurements and shows that the SP and FW control treatments were anoxic. Previ- 
ous studies have shown the potential importance of anoxygenic photosynthesis by Cyanobacteria (using $\mathrm{H}_{2} \mathrm{~S}$ as the electron donor), especially when exposed to high concentrations of sulfide (Padan 1979, 1989, Cohen et al. 1986, de Wit et al. 1988, Pinckney \& Paerl 1997), which may be attributed to a reversible inhibition of photosystem II (PSII) by $\mathrm{H}_{2} \mathrm{~S}$ when concentrations exceed $3 \mu \mathrm{M}$ (Jørgensen et al. 1986, Pringault \& Garcia Pichel 2000, Wieland \& Kühl 2000). Furthermore, salt stress results in an increase in the amount of P700 and PSI (photosystem I) reaction centers for some Cyanobacteria, possibly enhancing anoxygenic photosynthesis (Sudhir \& Murthy 2004). Although the quantum yield for cyanobacterial anoxygenic photosynthesis is low, there is sufficient carbon fixation for survival (Oren et al. 1977). For mats in Salt Pond, the rates of $\mathrm{CO}_{2}$ fixation in mats exposed to hypersalinity were nearly one-half the rates at normal salinities while oxygenic photosynthesis was not detectable (Pinckney \& Paerl 1997, Paerl et al. 2003). The addition of seawater likely reduced sulfide concentrations in the upper mat layers directly by dilution and indirectly by enhancing cyanobacterial oxygenic photosynthesis and subsequent oxygenation of mat surface layers.

The discriminant analysis suggests that the collective changes in photopigment abundances were related to both nutrient status and incubation salinity, except for mats incubated in the hypersaline Salt Pond water. Under hypersaline (300 $\left.\mathrm{g} \mathrm{l}^{-1}\right)$ conditions, anoxygenic phototrophic bacteria were the only group to show a small but significant response to nutrient additions. In these microbial mats, both salinity and nutrient status seem to determine, interactively, the structure and function of the photoautotroph community.
Nutrient additions alter community structure (photopigment composition), but the nature of the response depends on salinity. Yannarell et al. (2006), using nifH and 16S rDNA sequence data, demonstrated that the composition of the cyanobacterial community in Salt Pond was less sensitive to desiccation stress and hence dominated the nitrogen-fixing community during dry months. However, when salinities were lowered, the community diversity of diazotrophs increased.

Collectively, these results suggest that, under hypersaline conditions, Cyanobacteria fix carbon using anoxygenic photosynthesis while anoxygenic phototrophic bacteria increase their relative abundance when nutrients ( $\mathrm{N}$ and $\mathrm{P}$ ) are supplied in excess (Fig. 7). Once salinity and/or sulfide stress is lowered, oxygenic photosynthesis allows the proliferation of Cyanobacteria and a corresponding reduction in the abundance of anoxygenic phototrophic bacteria. When nutrient stress is reduced, mats respond by increasing biomass (using either anoxygenic or oxygenic photosynthesis, or both). High and low salinity conditions control the diversity and location, both horizontally and vertically, of key microbes responsible for carbon and nitrogen cycling within the mat community (Paerl \& Yanarell 2010). In this hypersaline system, seasonal variations in environmental conditions result in structural changes in the mat community which alter the rates of major processes, such as oxygenic photosynthesis and heterotrophy, and illustrates the cyclic behavior of microbial dormancy and proliferation in this extreme environment.

The ability of the Salt Pond benthic microbial community to rapidly (within days) undergo alterations in community structure (relative abundances of photoau-
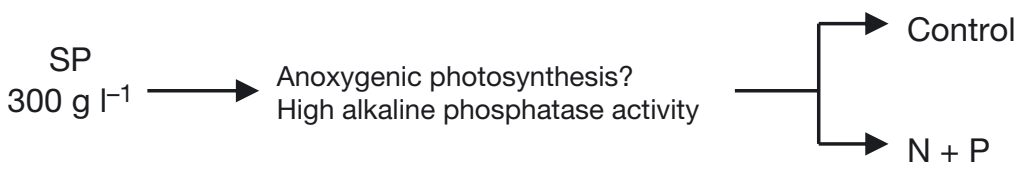

Higher bacteriochlorophyll a
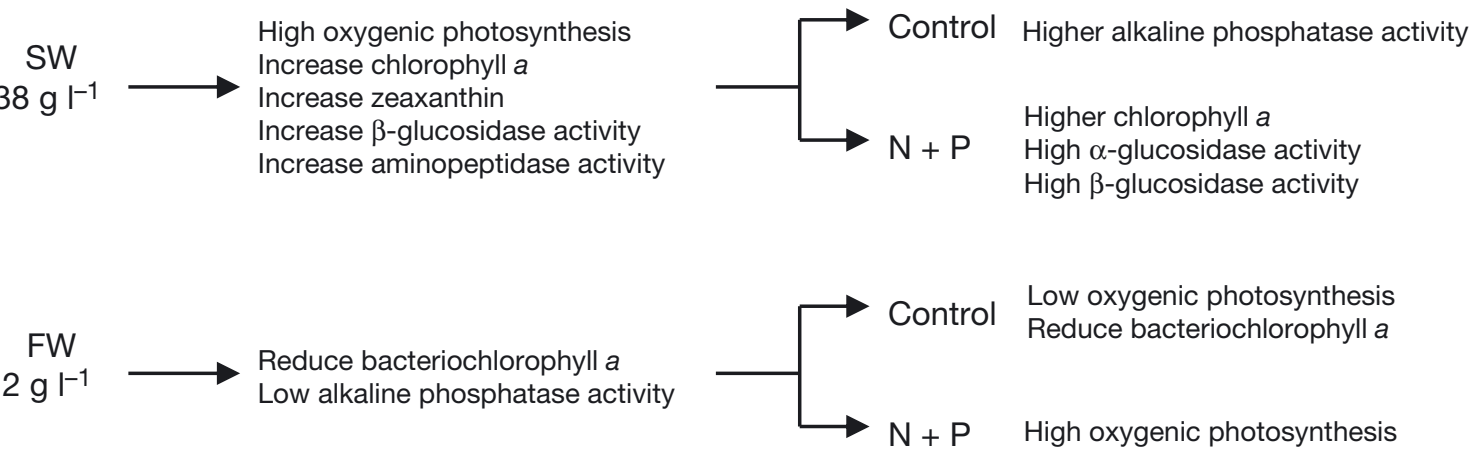

High oxygenic photosynthesis Increase chlorophyll a Increase $\beta$-glucosidase activity Increase aminopeptidase activity
Low oxygenic photosynthesis Reduce bacteriochlorophyll a

High $\beta$-glucosidase activity

High oxygenic photosynthesis

Fig. 7. Summary of microbial mat responses to changes in salinity and nutrient additions. FW $=$ freshwater, SW $=$ seawater, $\mathrm{SP}=$ Salt Pond, $\mathrm{N}+\mathrm{P}=$ nutrient addition 
totrophs) and function (rates of photosynthesis and heterotrophy) in response to major salinity and nutrient changes illustrates the close coupling of biotic and abiotic processes in this extreme environment. Furthermore, the community response to the alleviation of salinity and nutrient stress individually differs from the simultaneous removal of both stressors. Both salinity and nutrients regulate community structure and function in this system. Cycles in nutrient input and salinity are primary forcing factors for the maintenance of a dynamic and diverse benthic microbial community in this hypersaline lagoon.

Acknowledgements. Funding for this project was provided by NSF Microbial Observatory Program (MCB-0132528). Technical support and field sampling assistance was provided by D. Marshalonis. We thank the staff of the Gerace Research Centre, College of the Bahamas, for logistical and laboratory arrangements. This is publication 1622 from the Belle W. Baruch Institute for Marine Biology and Coastal Research.

\section{LITERATURE CITED}

Abed RMM, Kohls K, de Beer D (2007) Effect of salinity changes on the bacterial diversity, photosynthesis and oxygen consumption of cyanobacterial mats from an intertidal flat of the Arabian Gulf. Environ Microbiol 9: $1384-1392$

Abed RMM, Kohls K, Schoon R, Scherf AK and others (2008) Lipid biomarkers, pigments and cyanobacterial diversity of microbial mats across intertidal flats of the arid coast of the Arabian Gulf (Abu Dhabi, UAE). FEMS Microbiol Ecol 65:449-462

Black M (1932) The algal sediments of Andros Island, Bahamas. Philos Trans R Soc Lond 222:165-191

> Camacho A, de Wit R (2003) Effect of nitrogen and phosphorus additions on a benthic microbial mat from a hypersaline lake. Aquat Microb Ecol 32:261-273

Cohen Y, Rosenberg E (1989) Microbial mats. American Society for Microbiology, Washington, DC

$>$ Cohen Y, Jørgensen BB, Revsbech NP, Poplawski R (1986) Adaptation to hydrogen sulfide of oxygenic and anoxygenic photosynthesis among cyanobacteria. Appl Environ Microbiol 51:398-407

de Wit R, van Boekel WHM, van Gemerden H (1988) Growth of the cyanobacterium Microcoleus chthonoplastes on sulfide. FEMS Microbiol Ecol 53:203-209

> Garcia-Pichel F, Kühl M, Nübel U, Muyzer G (1999) Salinitydependent limitation of photosynthesis and oxygen exchange in microbial mats. J Phycol 35:227-238

Green SJ, Blackford C, Bucki P, Jahnke LL, Prufert-Bebout L (2008) A salinity and sulfate manipulation of hypersaline microbial mats reveals stasis in the cyanobacterial community structure. ISME J 2:457-470

- Hoppe HG (1983) Significance of exoenzymatic activities in the ecology of brackish water measurement by means of methylumbelliferyl substrates. Mar Ecol Prog Ser 11: 299-308

> Jørgensen BB, Cohen Y, Revsbech NP (1986) Transition from anoxygenic to oxygenic photosynthesis in a Microcoleus chthonoplastes cyanobacterial mat. Appl Environ Microbiol 51:408-417
Neumann A, Gebelein C, Scoffin T (1970) The composition, structure, and erodability of subtidal mats, Abaco, Bahamas. J Sed Res 40:274-297

Omoregie EO, Crumbliss LL, Bebout BM, Zehr JP (2004) Determination of nitrogen-fixing phylotypes in Lyngbya sp and Microcoleus chthonoplastes cyanobacterial mats from Guerrero Negro, Baja California, Mexico. Appl Environ Microbiol 70:2119-2128

Oren A (2000) Salts and brines. In: Whitton BA, Potts M (eds) The ecology of cyanobacteria. Kluwer, Dordrecht, p 281-306

Oren A (2009) Saltern evaporation ponds as model systems for the study of primary production processes under hypersaline conditions. Aquat Microb Ecol 56:193-204

> Oren A, Padan E, Avron M (1977) Quantum yields for oxygenic and anoxygenic photosynthesis in the cyanobacterium Oscillatoria limnetica. Proc Natl Acad Sci USA 74: $2152-2156$

Padan E (1979) Facultative anoxygenic photosynthesis in cyanobacteria. Annu Rev Plant Physiol 30:27-40

Padan E (1989) Combined molecular and physiological approach to anoxygenic photosynthesis of cyanobacteria. In: Cohen Y, Rosenberg E (eds) Microbial mats: physiological ecology of benthic microbial communities. American Society for Microbiology, Washington, DC, p 277-282

Paerl HW, Yanarell AC (2010) Environmental dynamics, community structure and function in a hypersaline microbial mat. In: Seckbach J, Oren A (eds) Microbial mats. Springer, Berlin, p 423-444

Paerl HW, Joye S, Fitzpatrick M (1993) Evaluation of nutrient limitation of $\mathrm{CO}_{2}$ and $\mathrm{N}_{2}$ fixation in marine microbial mats. Mar Ecol Prog Ser 101:297-306

Paerl HW, Fitzpatrick M, Bebout B (1996) Seasonal nitrogen fixation dynamics in a marine microbial mat: potential roles of cyanobacteria and microheterotrophs. Limnol Oceanogr 41:419-427

Paerl HW, Pinckney JL, Steppe TF (2000) Cyanobacterialbacterial mat consortia: examining the functional unit of microbial survival and growth in extreme environments. Environ Microbiol 2:11-26

> Paerl HW, Steppe TF, Buchan KC, Potts M (2003) Hypersaline cyanobacterial mats as indicators of elevated tropical hurricane activity and associated climate change. Ambio 32: 87-90

> Pinckney JL, Paerl HW (1997) Anoxygenic photosynthesis and nitrogen fixation by a microbial mat community in a Bahamian hypersaline lagoon. Appl Environ Microbiol 63: 420-426

> Pinckney JL, Zingmark R (1993) Photophysiological responses of intertidal benthic microalgal communities to in situ light environments: methodological considerations. Limnol Oceanogr 38:1373-1383

Pinckney JL, Paerl HW, Bebout B (1995) Salinity control of benthic microbial mat community production in a Bahamian hypersaline lagoon. J Exp Mar Biol Ecol 187:223-237

Pinckney JL, Millie D, Howe K, Paerl H, Hurley J (1996) Flow scintillation counting of ${ }^{14} \mathrm{C}$-labeled microalgal photosynthetic pigments. J Plankton Res 18:1867-1880

$>$ Pringault O, Garcia-Pichel F (2000) Monitoring of oxygenic and anoxygenic photosynthesis in a unicyanobacterial biofilm, grown in a benthic gradient chamber. FEMS Microbiol Ecol 33:251-258

Revsbech N, Jørgensen B (1986) Microelectrodes: their use in microbial ecology. Adv Microb Ecol 9:273-352

Shaklee RV (1996) Weather and climate of San Salvador Island, Bahamas. Bahamian Field Station Publications, San Salvador, Bahamas 
Sherwood JE, Stagnitti F, Kokkinn MJ, Williams WD (1991) Dissolved oxygen concentrations in hypersaline waters. Limnol Oceanogr 36:235-250

Stal L (1995) Physiological ecology of cyanobacteria in microbial mats and other communities. New Phytol 131:1-32

Sudhir P, Murthy SDS (2004) Effects of salt stress on basic processes of photosynthesis. Photosynthetica 42:481-486

Wieland A, Kühl M (2000) Short-term temperature effects on oxygen and sulfide cycling in a hypersaline cyanobacterial mat (Solar Lake, Egypt). Mar Ecol Prog Ser 196:87-102

Wieland A, Kühl M (2006) Regulation of photosynthesis and oxygen consumption in a hypersaline cyanobacterial mat

Editorial responsibility: Douglas Capone,

Los Angeles, California, USA
(Camargue, France) by irradiance, temperature and salinity. FEMS Microbiol Ecol 55:195-210

Yannarell AC, Paerl HW (2007) Effects of salinity and light on organic carbon and nitrogen uptake in a hypersaline microbial mat. FEMS Microbiol Ecol 62:345-353

Yannarell AC, Steppe TF, Paerl HW (2006) Genetic variance in the composition of two functional groups (diazotrophs and cyanobacteria) from a hypersaline microbial mat. Appl Environ Microbiol 72:1207-1217

Yannarell AC, Steppe TF, Paerl HW (2007) Disturbance and recovery of microbial community structure and function following Hurricane Frances. Environ Microbiol 9: 576-583

Submitted: July 23, 2010; Accepted: November 5, 2010

Proofs received from author(s): January 26, 2011 